\title{
Anti-bacterial and Anti-mold Efficiency of Silver Nanoparticles Present in Melamine-laminated Particleboard Surfaces
}

\begin{abstract}
Erik Nosál, and Ladislav Reinprecht *
Laminated surfaces of wooden composites are created from decorative papers and impregnation thermosetting resins, mainly melamineformaldehyde (MF). This type of surface treatment is not always resistant to microorganisms, especially when polluted with organic substances. Bioactive additives are often needed to improve the microbial resistance. In this study, silver nanoparticles (Ag-NPs), in amounts of $0.15 \times 10^{-3} \mathrm{wt} . \%$, $0.5 \times 10^{-3}$ wt. $\%, 1.5 \times 10^{-3}$ wt. $\%, 5 \times 10^{-3}$ wt. $\%, 15 \times 10^{-3}$ wt. $\%$, and $50 \times$ $10^{-3}$ wt.\% were added to MF resin. The presence of Ag-NPs in the laminated surfaces of the particleboards improved their anti-bacterial and anti-mold resistances. Growth of gram-positive bacterium Staphylococcus aureus on the sterilized surfaces decreased by approximately $53.7 \%$ at most, while the growth of gram-negative bacterium Escherichia coli decreased by up to $100 \%$. The anti-mold resistance of the polluted laminated surfaces containing Ag-NPs increased against Penicillium brevicompactum by up to $62.5 \%$, but there was almost no improvement against Aspergillus niger. The Ag-NPs did not affect the resistance of the laminated surfaces towards aggressive chemicals and only minimally towards dry heat at $180^{\circ} \mathrm{C}$. This inorganic biocide decreased the abrasion resistance of the laminated surfaces by up to $12.6 \%$.
\end{abstract}

Keywords: Ag nanoparticles; Antimicrobial surface; Bacteria; Melamine laminate; Molds

Contact information: Technical University in Zvolen, Faculty of Wood Sciences and Technology, Department of Wood Technologies, T. G. Masaryka 24, SK-96053 Zvolen, Slovakia;

* Corresponding author: reinprecht@tuzvo.sk

\section{INTRODUCTION}

Surface lamination of wood-based materials consists of pressing one layer or multiple layers of thin papers initially impregnated with thermosetting resins. The interconnection between the laminate layer and underlying material is ensured by melting the resin and subsequently curing it (Reinprecht and Perlác 1983). Mostly, décor papers impregnated with amino thermosetting resins are used for the lamination of the surface of wood-based composites, e.g. for particleboards and fiberboards (Roberts and Evans 2005). Nowadays, lamination is done in short-cycle hot presses, within which impregnated décor papers are pressed onto wood-based composites for a few seconds at high temperatures and pressures (Kandelbauer and Teischinger 2010; Nosál' and Reinprecht 2017). Laminated surfaces of wood-based materials are commercially produced in many designs and various colors, or with an imitation of wood, rocks, wall tiles, etc. (Kohlmayr et al. 2014). Although laminated surfaces of wood-based composites secure a certain level of resistance against bacteria and microscopic fungi, these surfaces are not sufficiently resistant against microorganisms when first polluted by organic substances (Vidholdová et al. 2015; Nosál' and Reinprecht 2017). Antimicrobial properties of laminated surfaces can be achieved 
through several methods (Nosál' and Reinprecht 2017). A lot of research has dealt with the possibility of creating antimicrobial surfaces in wood-based composites, including studies about their physical and chemical modification (Magina et al. 2016; Saleem and Bokhari 2017). Antimicrobial laminates can also be created by treatment of impregnation resin with organic or inorganic biocides (Hanrahan et al. 2006; Kim and Kim 2006).

Inorganic biocides, especially in the form of nanoparticles, added into the surface layers of laminated materials can remarkably improve antimicrobial properties. Biocides added into amino impregnation resins should be chemically and physically inert to the resin to avoid a decrease in the final quality of the laminated surfaces. A biocidal treatment of amino resins could theoretically be used several metal nanoparticles (e.g. Ag, $\mathrm{Co}, \mathrm{Cu}$ ) and metal-oxide nanoparticles (e.g. $\mathrm{CuO}, \mathrm{TiO}_{2}, \mathrm{ZnO}$ ), which have a good inhibition effect against bacteria (Kamal et al. 2016, Khan et al. 2016, Ali et al. 2017) and fungi (Reinprecht et al. 2015, Nosál' and Reinprecht 2018). In previous experiments, good results with $\mathrm{ZnO}$ nanoparticles have been achieved at their application into melamine-laminated surfaces of particleboards (Nosál' and Reinprecht 2017) as well as into a whole matter of particleboards (Reinprecht et al. 2018).

Silver nanoparticles (Ag-NPs) are well-known biocide additives, potentially applied also into melamine-formaldehyde (MF) resins for laminated surfaces. The numerous favorable properties of Ag-NPs have led them to be used in many industrial sectors. Silver nanoparticles are often used as an antimicrobial/disinfectant agent in biomedicine (Panáček et al. 2006; Lim et al. 2015; Salar et al. 2015), in air and water purification, cosmetics, the textile industry, packaging materials, and home appliances, such as washing machines, refrigerators, and others (Eckhardt et al. 2013; Carbone et al. 2016). Commercial products contain various amounts of Ag-NPs from an almost undetectable level up to $700 \mathrm{mg} / \mathrm{kg}$ (Bauer et al. 2016). The antimicrobial efficiency of Ag-NPs strongly depends on the particle size because particles with smaller dimensions can more easily penetrate microbial cells. Likewise, smaller particles have a larger active surface, and therefore there is greater contact between the nanoparticle and microbial cells (Lok et al. 2006). Generally, the minimum inhibitory concentration of nanoparticles against microbes decreases with a decreasing particle size (Martínez-Castañón et al. 2008).

The aim of this study was a complex analysis of selected bactericidal, fungicidal, and user properties of melamine-laminated surfaces of particleboards (PBs) containing AgNPs added to the MF resin at various amounts.

\section{EXPERIMENTAL}

\section{Materials}

Commercial PBs (Kronospan Bučina DDD, Co. Ltd., Zvolen, Slovakia) with a thickness of $16 \mathrm{~mm}$ were used as an underlay. White décor papers (UNI white 0500) (Malta Décor Sp. Z o. o., Poznan, Poland) with an area weight of $90 \mathrm{~g} / \mathrm{m}^{2}$ were used for impregnation with basic and modified MF resins. The basic MF resin was produced by Kronospan Bučina DDD, Co. Ltd. at a melamine to formaldehyde molar ratio of 1 to 1.72 and was workable in $2 \mathrm{~d}$ with a preserved dynamic viscosity of $61.5 \mathrm{mPa} \cdot \mathrm{s}$ and dry mass of 58\%. The Ag-NPs (US Research Nanomaterials, Inc., Houston, TX, USA) had the following characteristics: average particle size of less than $15 \mathrm{~nm}$ and $5 \mathrm{wt} \%$ in water. 


\section{$M F$ resin modification with Ag-NPs}

The MF resin was modified with silver nanoparticles (Ag-NPs) present in amounts of $0.15 \times 10^{-3} \mathrm{wt} \%, 0.5 \times 10^{-3} \mathrm{wt} \%, 1.5 \times 10^{-3} \mathrm{wt} \%, 5 \times 10^{-3} \mathrm{wt} \%, 15 \times 10^{-3} \mathrm{wt} \%$, and $50 \times$ $10^{-3} \mathrm{wt} \%$. The modified MF resins, before using for impregnation of papers, had been catalyzed with the hardener DeuroCure KS (Deurowood, Hard, Austria). The condensing time for all of the resins was $330 \mathrm{~s} \pm 15 \mathrm{~s}$ at $100{ }^{\circ} \mathrm{C}$.

\section{Impregnation of the papers with MF resins}

White décor papers with the dimensions $300 \mathrm{~mm} \times 280 \mathrm{~mm}$ were impregnated on a laboratory mechanical applicator with the basic and modified MF resins to achieve uniform saturation and a retention of $120 \mathrm{~g} / \mathrm{m}^{2} \pm 10 \mathrm{~g} / \mathrm{m}^{2}$. A uniform dispersion of Ag-NPs in the MF resins used for the impregnation process was achieved by mechanical stirring (Makita 6600, Makita Corporation, Anjō, Japan) at $250 \mathrm{rpm}$ for $3 \mathrm{~min}$. The impregnated papers were then pre-cured in a laboratory kiln (Eccocell 55 - Comfort, MMM Medcenter Einrichtung $\mathrm{GmbH}$, Munich, Germany) for $3 \mathrm{~min}$ at $160{ }^{\circ} \mathrm{C} \pm 3{ }^{\circ} \mathrm{C}$.

\section{Preparation of the laminated PBS}

The pre-cured impregnated papers were pressed onto PBs $(300 \mathrm{~mm} \times 280 \mathrm{~mm})$ with a laboratory press (Table Press TP 600, Fontijne Presses \& Services BV, Barendrecht, Netherlands) at a pressure of $0.3 \mathrm{MPa}$ and temperature of $175^{\circ} \mathrm{C}$ for $4 \mathrm{~min}$. The thicknesses of the laminated layers on the PB surfaces ranged from $0.2022 \mathrm{~mm}$ to $0.2069 \mathrm{~mm}$ and were not remarkably influenced by the Ag dispersion amount. From the laminated PBs, samples were prepared with the dimensions $50 \mathrm{~mm} \times 50 \mathrm{~mm}$ for the bacterial and mold tests. Samples with the dimensions $100 \mathrm{~mm} \times 100 \mathrm{~mm}$ were used for the abrasion test, and samples with the dimensions $250 \mathrm{~mm} \times 250 \mathrm{~mm}$ were used for the resistance tests against aggressive chemicals and dry heat.

\section{Methods}

\section{Bacterial test}

Staphylococcus aureus ATCC-25923 as a representative of gram-positive bacteria and Escherichia coli ATCC-25922 as a representative of gram-negative bacteria (from the microorganism collection at the Department of Clinical Microbiology of Hospital in Zvolen, Slovakia) were used for the bacterial test.

Samples of laminated PBs with cleaned (using a mixture of $96 \%$ ethanol and 2propanol at a weight ratio of 8.8:1.2) and sterilized surfaces (twice by ultraviolet light for $20 \mathrm{~min}$ ) were placed into sterilized Petri dishes and inoculated with $0.1 \mathrm{~mL}$ of the bacterial suspensions. Two densities of bacterial suspensions, i.e., $0.5^{*}\left(1.5 \times 10^{8} \mathrm{CFU} / \mathrm{mL}\right)$ and $1.0^{*}$ $\left(3.0 \times 10^{8} \mathrm{CFU} / \mathrm{mL}\right)$, were applied in the physiological solutions, according to the McFarland scale. Incubation of bacteria on the inoculated laminated surfaces was performed at $37{ }^{\circ} \mathrm{C}$ for $48 \mathrm{~h}$. The bacteria were then stripped from the laminated surfaces using a sterile swab and put in a liquid culture medium for $48 \mathrm{~h}$. Finally, the bacteria were pre-inoculated from the liquid medium into the sodium chloride diagnostic soil in the Petri dishes.

The anti-bacterial resistance of the laminated PBs in the diagnostic soil was assessed on the basis of the bacterial activity and valued from 0 to higher numbers in $\mathrm{CFU} / \mathrm{mL}$. 


\section{Mold test}

The microscopic fungi Aspergillus niger and Penicillium brevicompactum (from the fungi collection at the Mycological laboratory of Technical University in Zvolen, Slovakia) were used in the mold test.

The laminated PB samples were all sterilized, and then one half of the samples were intentionally polluted. Intentional pollution of the top surfaces of the samples was done with a $15 \mathrm{wt} \%$ mixed solution of proteins, sugars, and lipids at a weight ratio of 8:1.3:0.7. The solution was applied with a sprayer (two sprays of $0.5 \mathrm{~mL}$ ) on the whole sample surface from a distance of $10 \mathrm{~cm}$. The mold tests were started by the placement of the samples into 100-mm Petri dishes filled with a 3-mm- to 4-mm-thick layer of Czapek-Dox agar (one sample per dish), and their top surfaces were inoculated with water spore suspensions of $A$. niger or $P$. brevicompactum. Incubation of the molds on the laminated surfaces lasted 4 weeks at a temperature of $27^{\circ} \mathrm{C}$ and relative humidity of $90 \%$.

The anti-mold resistance of the laminated surfaces was evaluated visually after $7 \mathrm{~d}$, $14 \mathrm{~d}, 21 \mathrm{~d}$, and $28 \mathrm{~d}$. The growth activity of the molds (GAM) was determined with the following scale from 0 to 4 using standard STN 490604 (1980), where 0 is no mold, 1 is up to $10 \%$ mold, 2 is up to $25 \%$ mold, 3 is up to $50 \%$ mold, and 4 is more than $50 \%$ mold on the top surface.

\section{Standard quality tests}

First, the laminated PB samples were conditioned for 1 week at a temperature of 23 ${ }^{\circ} \mathrm{C} \pm 2{ }^{\circ} \mathrm{C}$ and a $50 \% \pm 5 \%$ relative humidity. Next, the top surfaces were tested for their resistance to cold liquids of aggressive chemicals, dry heat, and abrasion in accordance with EN 12720:2009+A1 (2013), EN 12722:2009+A1 (2013), and EN 15185 (2011), respectively.

\section{RESULTS AND DISCUSSION}

\section{Bacterial Test}

The results of the bacterial activity on the laminated surfaces of the PBs are shown in Table 1.

Table 1. Bacterial Activity on the Laminated Surfaces after Application of Ag-NPs in the MF Resins

\begin{tabular}{|c|c|c||c|c|}
\hline \multirow{2}{*}{$\begin{array}{c}\text { Ag-NPs in MF } \\
\text { (wt\%) }\end{array}$} & \multicolumn{3}{|c|}{ Bacterial Activity $\left(\mathbf{1 0}^{\mathbf{8}} \mathbf{C F U} / \mathbf{m L}\right)$} \\
\cline { 2 - 5 } & \multicolumn{2}{|c|}{ S. aureus } & \multicolumn{2}{c|}{ E. coli } \\
\cline { 2 - 5 } & $\mathbf{0 . 5}^{\star}$ & $\mathbf{1 . 0}^{\star}$ & $\mathbf{0 . 5}^{*}$ & $\mathbf{1 . 0}^{*}$ \\
\hline 0 & 0.41 & 0.73 & 0.30 & 0.62 \\
\hline $0.15 \times 10^{-3}$ & 0.36 & 0.74 & 0.28 & 0.61 \\
\hline $0.5 \times 10^{-3}$ & 0.32 & 0.65 & 0.18 & 0.47 \\
\hline $1.5 \times 10^{-3}$ & 0.32 & 0.65 & 0.09 & 0.20 \\
\hline $5 \times 10^{-3}$ & 0.28 & 0.52 & 0.00 & 0.04 \\
\hline $15 \times 10^{-3}$ & 0.25 & 0.55 & 0.00 & 0.02 \\
\hline $50 \times 10^{-3}$ & 0.19 & 0.42 & 0.00 & 0.02 \\
\hline$N$ (number of tested samples in one series) $=6$ \\
\hline
\end{tabular}


The addition of Ag-NPs to the impregnation MF resin caused a moderate reduction in the gram-positive bacterium $S$. aureus activity on the laminated surfaces. The highest reduction of this bacterium, approximately $53.7 \%$ from $0.41 \times 10^{8} \mathrm{CFU} / \mathrm{mL}$ to $0.19 \times 10^{8}$ $\mathrm{CFU} / \mathrm{mL}$ (for $0.5^{*} \mathrm{McFarland}$ ) and approximately $42.5 \%$ from $0.73 \times 10^{8} \mathrm{CFU} / \mathrm{mL}$ to 0.42 $\times 10^{8} \mathrm{CFU} / \mathrm{mL}$ (for $1^{*}$ McFarland), was observed on the laminated surfaces containing the highest Ag-NP amount, i.e., when the MF resin contained $50 \times 10^{-3} \mathrm{wt} \%$ silver. In contrast, the Ag-NPs remarkably reduced (up to $96.8 \%$ from $0.62 \times 10^{8} \mathrm{CFU} / \mathrm{mL}$ to $0.02 \times 10^{8}$ $\mathrm{CFU} / \mathrm{mL}$ for the $1 *$ McFarland density) or even totally reduced (up to $100 \%$ from $0.30 \times$ $10^{8} \mathrm{CFU} / \mathrm{mL}$ to $0 \mathrm{CFU} / \mathrm{mL}$ for the $0.5^{*} \mathrm{McFarland}$ density) the activity of the gramnegative bacterium $E$. coli for lower amounts of Ag-NPs in the laminated surfaces. An example of this was when the MF resin contained $15 \times 10^{-3}$ wt $\%$ or only $5 \times 10^{-3}$ wt $\%$ silver (Table 1).

Based on the bacterial test results, it was concluded that Ag-NPs in the melaminelaminated surfaces were able to inhibit bacterial growth. However, the Ag-NPs had different efficiencies for the gram-positive and gram-negative bacteria. The silver only partially suppressed the gram-positive bacterium $S$. aureus, but it was lethal to the gramnegative bacterium E. coli. Different efficiencies of Ag-NPs against the two types of bacteria were also observed in previous studies (Yoon et al. 2007; Li et al. 2011; Suchomel et al. 2015). Kim and Kim (2006) reported a high efficiency of Ag-NPs in melamine laminates against $E$. coli, when the number of bacteria on the tested specimen surfaces was reduced by more than $98 \%$. Testing other materials, a significant inhibition of $E$. coli was achieved with $\mathrm{CuO}$ (Khan et al. 2016) and $\mathrm{TiO}_{2}$ (Kamal et al. 2016) nanoparticles in combination with chitosan.

\section{Mold Test}

The results of the GAM on the cleaned and sterilized laminated surfaces of the PBs are shown in Table 2. For the polluted laminated surfaces, the results are shown in Table 3.

The cleaned and sterilized laminated surfaces containing smaller or higher amounts of Ag-NPs were completely resistant to the growth of both A. niger and P. brevicompactum (Table 2 and Fig. 1). However, a slight growth of $A$. niger was observed on the reference untreated laminated surfaces after $21 \mathrm{~d}$ and $28 \mathrm{~d}$ of incubation (GAM of individual samples from 1 to 2) (Table 2, and Figs. 1a, 1b, 1c, and 1d).

Table 2. Mold Activity on the Cleaned Laminated Surfaces

\begin{tabular}{|c|c|c|c|c|c|c|c|c|}
\hline \multirow{3}{*}{$\begin{array}{l}\text { Ag-NPs in } \\
\text { MF (wt \%) }\end{array}$} & \multicolumn{8}{|c|}{ GAM - On Cleaned Surfaces ( 0 to 4 ) } \\
\hline & \multicolumn{4}{|c|}{ A. niger } & \multicolumn{4}{|c|}{ P. brevicompactum } \\
\hline & $7 d$ & $14 d$ & $21 \mathrm{~d}$ & $28 d$ & $7 d$ & $14 d$ & $21 d$ & $28 \mathrm{~d}$ \\
\hline 0 & 0 & 0 & 1 & 1.5 & 0 & 0 & 0 & 0 \\
\hline $0.15 \times 10^{-3}$ & 0 & 0 & 0 & 1 & 0 & 0 & 0 & 0 \\
\hline $0.5 \times 10^{-3}$ & 0 & 0 & 0 & 0 & 0 & 0 & 0 & 0 \\
\hline $1.5 \times 10^{-3}$ & 0 & 0 & 0 & 0 & 0 & 0 & 0 & 0 \\
\hline $5 \times 10^{-3}$ & 0 & 0 & 0 & 0 & 0 & 0 & 0 & 0 \\
\hline $15 \times 10^{-3}$ & 0 & 0 & 0 & 0 & 0 & 0 & 0 & 0 \\
\hline $50 \times 10^{-3}$ & 0 & 0 & 0 & 0 & 0 & 0 & 0 & 0 \\
\hline$N=6$ & & & & & & & & \\
\hline
\end{tabular}

Nosál' \& Reinprecht (2019). "Ag NPs in particleboard," BioResources 14(2), 3914-3924. 3918 


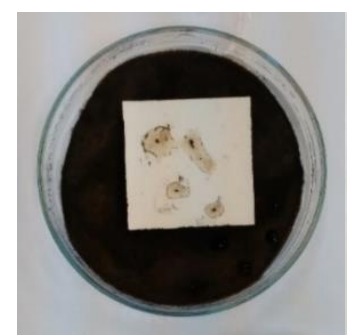

(a)

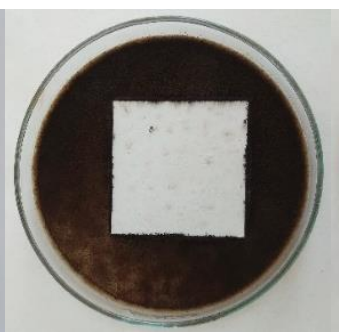

(b)

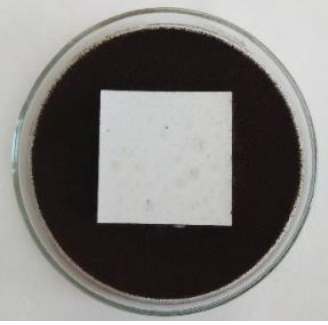

(c)

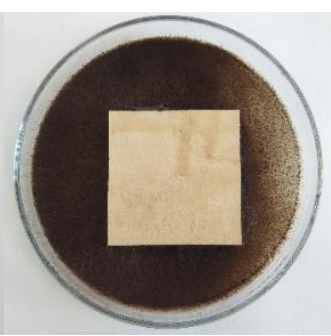

(d)

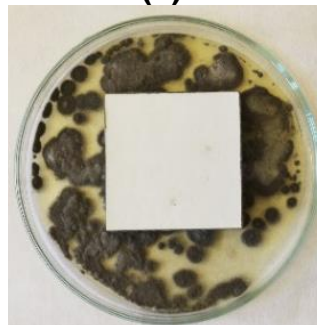

(e)

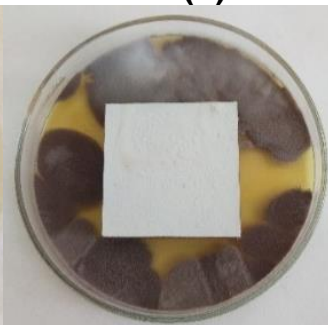

(f)

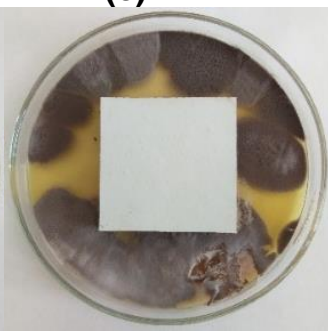

(g)

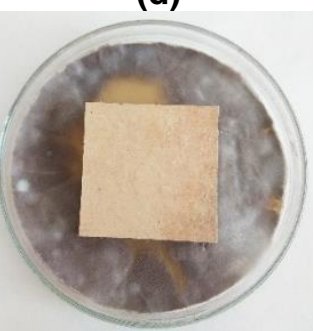

(h)

Fig. 1. Top surfaces of the sterilized laminated PBs inoculated with $A$. niger /(a) 0 wt\%, (b) $0.15 \times$ $10^{-3} \mathrm{wt} \%$, (c) $5 \times 10^{-3} \mathrm{wt} \%$, and (d) $50 \times 10^{-3} \mathrm{wt} \%$ of Ag-NPs in MF/ or with P. brevicompactum $/(\mathrm{e}) 0 \mathrm{wt} \%$ (f) $0.15 \times 10^{-3} \mathrm{wt} \%$, (g) $5 \times 10^{-3} \mathrm{wt} \%$, and (h) $50 \times 10^{-3} \mathrm{wt} \%$ of Ag-NPs in MF/ after $28 \mathrm{~d}$ of incubation

In contrast, the intentionally polluted "contaminated" laminated surfaces of the PBs were markedly attacked by molds (Table 3 and Fig. 2). The polluted reference laminates without Ag-NPs were not able to inhibit the growth activity of both mold species. The presence of silver in the laminated surfaces only minimally inhibited a strong growth of $A$. niger, but it was able to inhibit $P$. brevicompactum more. Nearly no growth reduction in $A$. niger by Ag-NPs was observed after $21 \mathrm{~d}$ and $28 \mathrm{~d}$ of the mold test, at which point almost all of the samples were over $50 \%$ covered by mycelia of this mold with a GAM of 3 to 4 (Table 3, and Figs. 2a, 2b, 2c, and 2d). However, the presence of Ag-NPs in the laminates caused a more apparent reduction in $P$. brevicompactum (up to $62.5 \%$ growth). Considerable growth inhibition of this mold on the polluted laminated surfaces occurred with Ag-NP contents $\geq 1.510^{-3} \mathrm{wt} \%$, where the mold growth on laminates was only up to $25 \%$ with a GAM of 1 to 2 (Table 3, and Figs. 2e, 2f, $2 \mathrm{~g}$, and $2 \mathrm{~h}$ ).

Table 3. Mold Activity on the Intentionally Polluted Laminated Surfaces

\begin{tabular}{|c|c|c|c|c|c|c|c|c|}
\hline \multirow{3}{*}{$\begin{array}{l}\text { Ag-NPs in } \\
\text { MF (wt.\%) }\end{array}$} & \multicolumn{8}{|c|}{ GAM - On Polluted Surfaces ( 0 to 4 ) } \\
\hline & \multicolumn{4}{|c|}{ A. niger } & \multicolumn{4}{|c|}{ P. brevicompactum } \\
\hline & $7 d$ & $14 d$ & $21 \mathrm{~d}$ & $28 d$ & $7 d$ & $14 d$ & $21 \mathrm{~d}$ & $28 d$ \\
\hline 0 & 2.5 & 4 & 4 & 4 & 2 & 3 & 4 & 4 \\
\hline $0.15 \times 10^{-3}$ & 2.5 & 4 & 4 & 4 & 2 & 3 & 3.5 & 3.5 \\
\hline $0.5 \times 10^{-3}$ & 2.5 & 4 & 4 & 4 & 1.5 & 2.5 & 2.5 & 2.5 \\
\hline $1.5 \times 10^{-3}$ & 2 & 4 & 4 & 4 & 1 & 2 & 2 & 2 \\
\hline $5 \times 10^{-3}$ & 2 & 3.5 & 4 & 4 & 1 & 2 & 2 & 2 \\
\hline $15 \times 10^{-3}$ & 1.5 & 2.5 & 3.5 & 3.5 & 1 & 1.5 & 1.5 & 1.5 \\
\hline $50 \times 10^{-3}$ & 1 & 2 & 3.5 & 3.5 & 0.5 & 1 & 1.5 & 1.5 \\
\hline$N=6$ & & & & & & & & \\
\hline
\end{tabular}




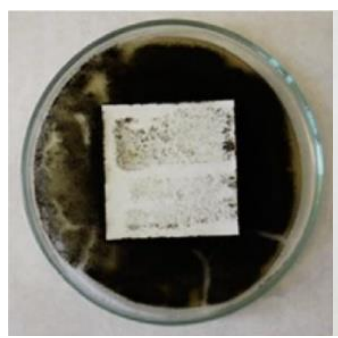

(a)

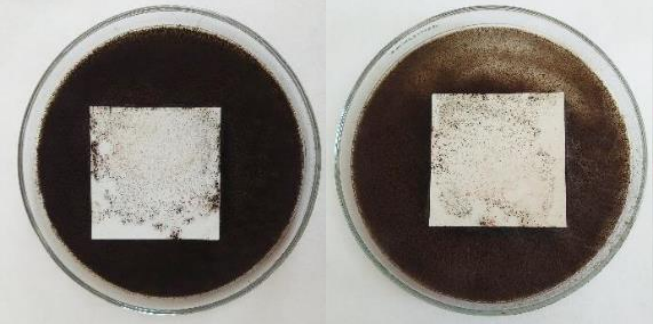

(b) (c)

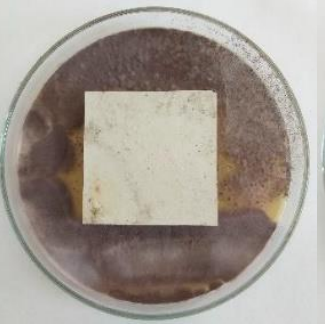

(g)

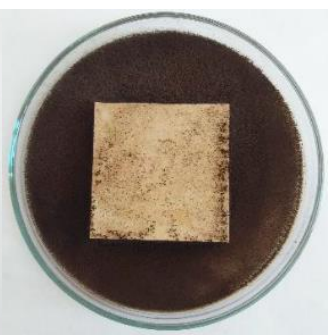

(d)

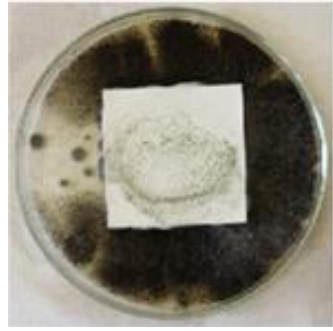

(e)

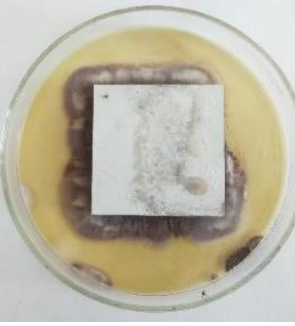

(f)

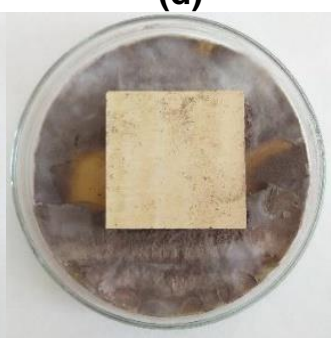

(h)

Fig. 2. Top surfaces of the intentionally polluted laminated PBs inoculated with $A$. niger /(a) 0 wt\%, (b) $0.15 \times 10^{-3} \mathrm{wt} \%$, (c) $5 \times 10^{-3} \mathrm{wt} \%$, and (d) $50 \times 10^{-3} \mathrm{wt} \%$ of $\mathrm{Ag}-\mathrm{NPs}$ in MF/ or with $P$. brevicompactum /(e) 0 wt $\%$ (f) $0.15 \times 10^{-3} \mathrm{wt} \%$, (g) $5 \times 10^{-3} \mathrm{wt} \%$, and (h) $50 \times 10^{-3} \mathrm{wt} \%$ of Ag-NPs in MF/ after $28 \mathrm{~d}$ of incubation

The anti-mold test results were divided into sterilized and intentionally polluted sample groups. The surfaces of the sterilized samples were resistant to growth of both $A$. niger and $P$. brevicompactum. This was explained by an absence of nutrient substances on the samples, and therefore mold developing was an impossibility (Kandelbauer and Widsten 2009). The presence of Ag-NPs in the melamine-laminated surfaces of the intentionally polluted samples only had a mild effect on $A$. niger growth, mainly in the first 2 weeks for the samples containing the highest amounts of Ag-NPs. In contrast, the resistance of the laminated surfaces against $P$. brevicompactum remarkably increased by adding Ag-NPs. These results were in accordance with Zhang et al. (2008), who reported a lower efficiency of Ag-NPs against A. niger compared with Penicillium sp.

\section{Standard Quality Tests}

The results of the standard quality tests of the laminated surfaces of the PBs are shown in Table 4.

The Ag-NPs in the laminated surfaces of the PBs had no or negligible negative effects on the standardized quality characteristics. This was explained by the assumption that Ag-NPs did not considerably change the structural composition of the cured MF resins in the final laminates when applied at relatively low concentrations. A remarkable decrease occurred only with the abrasion resistance of the laminated PBs, where a maximum decrease of $12.6 \%$ was observed for the laminates prepared with the highest Ag-NP concentration in the MF resin $\left(50 \times 10^{-3} \mathrm{wt} \%\right)$ (Table 4). This decrease was explained by the interaction of the small solid nanoparticles of silver not chemically bonded with the cured MF resin in the laminates and the abrasive sandpaper, and probably by a certain change in the chemical structure of the laminates caused by the presence of Ag-NPs.

It should also be emphasized that the laminates containing the highest amounts of Ag-NPs had a darker color with grey-brown shades (Figs. 1 and 2). 
Table 4. Resistance of the Laminated Surfaces to Aggressive Chemicals, Dry Heat, and Abrasion

\begin{tabular}{|c|c|c|c|c|c|c|c|c|}
\hline \multirow{2}{*}{\multicolumn{2}{|c|}{ Tested Parameter }} & \multicolumn{7}{|c|}{ Ag-NPs in MF (wt\%) } \\
\hline & & \multirow{2}{*}{$\begin{array}{l}0 \\
4\end{array}$} & \multirow{2}{*}{$\begin{array}{c}0.15 \times \\
10^{-3} \\
4 \\
\end{array}$} & \multirow{2}{*}{$\begin{array}{c}0.5 \times \\
10^{-3} \\
4 \\
\end{array}$} & \multirow{2}{*}{$\begin{array}{c}1.5 \times \\
10^{-3} \\
4\end{array}$} & \multirow{2}{*}{$\begin{array}{c}5 \times \\
10^{-3} \\
4 \\
\end{array}$} & \multirow{2}{*}{$\begin{array}{c}15 \times \\
10^{-3} \\
4\end{array}$} & \multirow{2}{*}{$\begin{array}{c}50 \times \\
10^{-3} \\
4\end{array}$} \\
\hline \multirow{8}{*}{ Chemicals } & Acetone & & & & & & & \\
\hline & Ethanol & 5 & 5 & 5 & 4 & 5 & 5 & 5 \\
\hline & Coffee & 4 & 3 & 4 & 4 & 4 & 4 & 4 \\
\hline & Ink & 5 & 5 & 5 & 5 & 5 & 5 & 5 \\
\hline & Ketones & 3 & 3 & 3 & 3 & 3 & 3 & 3 \\
\hline & Oil & 5 & 5 & 5 & 5 & 5 & 5 & 5 \\
\hline & Tea & 4 & 4 & 4 & 4 & 4 & 4 & 4 \\
\hline & Water & 5 & 5 & 5 & 5 & 5 & 5 & 5 \\
\hline \multicolumn{2}{|c|}{ Dry Heat $\left(180^{\circ} \mathrm{C}\right)$} & 4 & 4 & 4 & 4 & 4 & 3 & 3 \\
\hline \multicolumn{2}{|c|}{$\begin{array}{c}\text { Relative Abrasion } \\
\text { Resistance (\%) }\end{array}$} & 100 & 100 & 98.77 & 98.72 & 97.44 & 96.16 & 87.43 \\
\hline
\end{tabular}

1 - noticeable differences, changed structure, or surface treatment fully or partially removed; 2 -noticeable differences, without structural changes; 3 - slight differences visible from several directions; 4 - slight gloss change visible only when the light source is mirrored and close to the tested surface; 5 - no visible changes; $N_{1}$ (number of tested samples in one series for the chemical and dry heat resistances) $=5$; and $N_{2}$ (number of tested samples in one series for the abrasion resistance) $=10$

\section{CONCLUSIONS}

1. The presence of Ag-NPs in the melamine-laminated surfaces of the PBs reduced the activity of the gram-positive bacterium S. aureus and the gram-negative bacterium $E$. coli. However, total effectiveness of the silver was observed only against $E$. coli.

2. The clean and sterilized laminated surfaces were resistant enough to mold growth, even without Ag-NP modification.

3. The presence of Ag-NPs in the polluted laminated surfaces, i.e., after their intentional pollution with organic substances, had only a mild effect on A. niger growth, but had a higher effect on $P$. brevicompactum growth.

4. The Ag-NPs had no or negligible negative effects on the resistance of the laminated surfaces to cold aggressive chemicals and dry heat.

5. The abrasion resistance of the laminated surfaces decreased by about $12 \%$ in the presence of the highest Ag-NP amount $\left(50 \times 10^{-3} \mathrm{wt} \%\right.$ of silver $)$ in MF resin.

\section{ACKNOWLEDGMENTS}

This work was supported by the Slovak Research and Development Agency under the contracts No. APVV-0200-12 and No. APVV-17-0583. 


\section{REFERENCES CITED}

Ali, F., Khan, S. B., Kamal, T., Anwar, Y., Alamry, K. A., and Asiri, A. M. (2017). "Bactericidal and catalytic performance of green nanocomposite based on chitosan/carbon black fiber supported monometallic and bimetallic nanoparticles," Chemosphere 188, 588-598. DOI: 10.1016/j.chemosphere.2017.08.118

Bauer, J., Kowal, K., Wysocka-Król, K., and Podbielska, H. (2016). "Nanosilver and silver-doped nanomaterials," in: Electrically Active Materials for Medical Devices, J. Bauer and S. A. M. Tofail (eds.), Imperial College Press, London, UK, pp. 209-244.

Carbone, M., Donia, D. T., Sabbatella, G., and Antiochia, R. (2016). "Silver nanoparticles in polymeric matrices for fresh food packaging," Journal of King Saud University - Science 28(4), 273-279. DOI: 10.1016/j.jksus.2016.05.004

Eckhardt, S., Brunetto, P. S., Gagnon, J., Priebe, M., Giese, B., and Fromm, K. M. (2013). "Nanobio silver: Its interactions with peptides and bacteria, and its uses in medicine," Chem. Rev. 113(7), 4708-4754. DOI: 10.1021/cr300288v

EN 12720:2009+A1 (2013). "Furniture - Assessment of surface resistance to cold liquids," European Committee for Standardization, Brussels, Belgium.

EN 12722:2009+A1 (2013). "Furniture - Assessment of surface resistance to dry heat," European Committee for Standardization, Brussels, Belgium.

EN 15185 (2011). "Furniture - Assessment of the surface resistance to abrasion," European Committee for Standardization, Brussels, Belgium.

Hanrahan, W., Pariano, L., and Ong, I. (2006). "Antimicrobial melamine resin and products made therefrom," U.S. Patent No. 20060068662A1.

Kamal, T., Anwar, Y., Khan, S. B., Chani, M. T. S., Asiri, A. M. (2016). “Anti-bacterial chitosan/zinc phthalocyanine fibers supported metallicand bimetallic nanoparticles for the removal of organic pollutants," Carbohydrate Polymers 148, 153-160. DOI: org/10.1016/j.carpol.2016.04.042

Kandelbauer, A., and Teischinger, A. (2010). "Dynamic mechanical properties of decorative papers impregnated with melamine formaldehyde resin," Eur. J. Wood Wood Prod. 68(2), 179-187. DOI: 10.1007/s00107-009-0356-7

Kandelbauer, A., and Widsten, P. (2009). “Antibacterial melamine resin surfaces for wood-based furniture and flooring," Prog. Org. Coat. 65(3), 305-313.

DOI: 10.1016/j.porgcoat.2008.12.003

Khan, S. B., Ali, F., Kamal, T., Anwar, Y., Asiri, A. M., Seo, J. (2016). "CuO embedded chitosan spheres as antibacterial adsorbent for dyes," International Journal of Biological Macromolecules 88, 113-119. DOI: 10.1016/j.ijbiomac.2016.03.026

Kim, J. S., and Kim, J.-H. (2006). "Anti-bacterial performance of colloidal silver-treated laminate wood flooring," Int. Biodeter. Biodegr. 57(3), 155-162.

DOI: 10.1016/j.ibiod.2006.02.002

Kohlmayr, M., Stultschnik, J., Teischinger, A., and Kandelbauer, A. (2014). "Drying and curing behavior of melamine formaldehyde resin impregnated papers," J. Appl. Polym. Sci. 131(3). DOI: 10.1002/app.39860

Li, W.-R., Xie, X.-B., Shi, Q.-S., Duan, S.-S., Ouyang, Y.-S., and Chen, Y.-B. (2011). "Antibacterial effect of silver nanoparticles on Staphylococcus aureus," Biometals 24(1), 135-141. DOI: 10.1007/s10534-010-9381-6

Lim, P. N., Chang, L., and Thian, E. S. (2015). "Development of nanosized silversubstituted apatite for biomedical applications: A review," Nanomed.-Nanotechnol. 11(6), 1331-1334. DOI: 10.1016/j.nano.2015.03.016 
Lok, C.-N., Ho, C.-M., Chen, R., He, Q.-Y., Yu, W.-Y., Sun, H., Tam, P. K.-H., Chiu, J.F., and Che, C.-M. (2006). "Proteomic analysis of the mode of antibacterial action of silver nanoparticles," J. Proteome Res. 5(4), 916-924. DOI: 10.1021/pr0504079

Magina, S., Santos, M. D., Ferra, J., Cruz, P., Portugal, I., and Evtuguin, D. (2016). "High pressure laminates with antimicrobial properties," Materials 9(2), 100. DOI: $10.3390 / \mathrm{ma9020100}$

Martínez-Castañón, G. A., Niño-Martínez, N., Martínez-Gutierrez, F., MartínezMendoza, J. R., and Ruiz, F. (2008). "Synthesis and antibacterial activity of silver nanoparticles with different sizes," J. Nanopart. Res. 10(8), 1343-1348.

DOI: $10.1007 / \mathrm{s} 11051-008-9428-6$

Nosál', E., and Reinprecht, L. (2017). "Anti-bacterial and anti-mold efficiency of ZnO nanoparticles present in melamine-laminated surfaces of particleboards," BioResources 12(4), 7255-7267. DOI: 10.15376/biores.12.4.7255-7267

Nosál, E., and Reinprecht, L. (2018). "Preparation and application of silver and zinc oxide nanoparticles in wood industry: A review," Acta Facultatis Xylologiae Zvolen 60(2), 5-23. DOI: 10.17423/afx.2018.60.2.01

Panáček, A., Kvítek, L., Prucek, R., Kolár, M., Večeřová, R., Pizúrová, N., Sharma, V. K., Nevěčná, T., and Zbořil, R. (2006). "Silver colloid nanoparticles: Synthesis, characterization, and their antibacterial activity," J. Phys. Chem. B 110(33), 1624816253. DOI: $10.1021 / j p 063826 h$

Reinprecht, L., and Perlác, J. (1983). “Čas laminovania vo viacetážovom lise ako funkcia vlastností impregnovaných papierov [The lamination time in multi platen press as a function of impregnated papers properties]," in: Syntema - Chemizace Dřevoprumyslu [Syntema - Chemistry of Wood Industry], Dům Techniky ČSVTS, Brno, Czechoslovakia, pp. 43-52.

Reinprecht, L., Vidholdová, Z., and Kožienka, M. (2015). "Decay inhibition of lime wood with zinc oxide nanoparticles in combination with acryl resin," Acta Facultatis Xylologiae Zvolen 57(1), 43-52.

Reinprecht, L., Iždinský, J., and Vidholdová, Z. (2018). "Biological resistance and application properties of particleboards containing nano-zinc oxide," Adv. Mater. Sci. Eng. 2018. DOI: 10.1155/2018/2680121

Roberts, R. J., and Evans, P. D. (2005). "Effect of manufacturing variables on surface quality and distribution of melamine formaldehyde resin in paper laminates," Compos. Part A-Appl. S. 36(1), 95-104. DOI: 10.1016/j.compositesa.2003.05.001

Salar, R. K., Sharma, P., and Kumar, N. (2015). "Enhanced antibacterial activity of streptomycin against some human pathogens using green synthesized silver nanoparticles," Resource-Efficient Technologies 1(2), 106-115.

DOI: 10.1016/j.reffit.2015.11.004

Saleem, R., and Bokhari, S. A. R. (2017). "Triclosan modified stable melamine resin as long-lasting antimicrobial agent," International Journal of Advanced Research 5(5), 1096-1108. DOI: 10.21474/IJAR01/4220

STN 490604 (1980). "Wood protection. Methods of determination of biocidal properties of wood preservatives," Slovak Office of Standards, Metrology and Testing of Slovak Republic, Bratislava, Slovakia.

Suchomel, P., Kvítek, L., Panáček, A., Prucek, R., Hrbáč, J., Večerová, R., and Zbořil, R. (2015). "Comparative study of antimicrobial activity of $\mathrm{AgBr}$ and $\mathrm{Ag}$ nanoparticles (NPs)," PLoS ONE 10(3). DOI: 10.1371/journal.pone.0119202 
Vidholdová, Z., Iždinský, J., Reinprecht, L., and Krokošová, J. (2015). “Activity of bacteria and moulds on surfaces of commercial wooden composites," Mater. Sci. Forum 818, 190-193. DOI: 10.4028/www.scientific.net/MSF.818.190

Yoon, K.-Y., Byeon, J. H., Park, J.-H., and Hwang, J. (2007). "Susceptibility constants of Escherichia coli and Bacillus subtilis to silver and copper nanoparticles," Sci. Total Environ. 373(2-3), 572-575. DOI: 10.1016/j.scitotenv.2006.11.007

Zhang, Y., Peng, H., Huang, W., Zhou, Y., and Yan, D. (2008). "Facile preparation and characterization of antimicrobial colloid Ag or Au nanoparticles," J. Colloid Interf. Sci. 325(2), 371-376. DOI: 10.1016/j.jcis.2008.05.063

Article submitted: January 18, 2019; Peer review completed: March 9, 2019; Revised version received: March 18, 2019; Accepted: March 20, 2019; Published: March 27, 2019.

DOI: $10.15376 /$ biores.14.2.3914-3924 